\title{
How can pharmacist remuneration systems in Europe contribute to generic medicine dispensing?
}

Pieter DYLST, Arnold VULTO, Steven SIMOENS.

\begin{abstract}
${ }^{*}$
Generic medicines can generate larger savings to health care budgets when their use is supported by incentives on both the supply-side and the demandside. Pharmacists' remuneration is one factor influencing the dispensing of generic medicines. Objective: The aim of this article is to provide an overview of different pharmacist remuneration systems for generic medicines in Europe, with a view to exploring how pharmacist remuneration systems can contribute to generic medicine dispensing.

Methods: Data were obtained from a literature review, a Master thesis in Pharmaceutical Care at the Catholic University of Leuven and a mailing sent to all members of the Pharmaceutical Group of the European Union with a request for information about the local remuneration systems of community pharmacists and the possible existence of reports on discounting practices.

Results: Pharmacists remuneration in most European countries consists of the combination of a fixed fee per item and a certain percentage of the acquisition cost or the delivery price of the medicines. This percentage component can be fixed, regressive or capped for very high-cost medicines and acts as a disincentive for dispensing generic medicines. Discounting for generic medicines is common practice in several European countries but information on this practice tends to be confidential. Nevertheless, data for Belgium, France, the Netherlands and United Kingdom indicated that discounting percentages varied from $10 \%$ to $70 \%$ of the wholesale selling price. Conclusion: Pharmacists can play an important role in the development of a generic medicines market. Pharmacists should not be financially penalized for dispensing generic medicines. Therefore, their remuneration should move towards a fee-for-performance remuneration instead of a price-dependent reimbursement which is currently used in many European countries. Such a fee-forperformance remuneration system provides a stimulus for generic medicines dispensing as pharmacists are not penalized for dispensing them
\end{abstract}

*Pieter DYLST. PharmD, PhD-candidate. Research Centre for Pharmaceutical Care \& Pharmaco-economics, K U Leuven. Leuven (Belgium).

Arnold VULTO. PharmD, PhD. Professor Hospital Pharmacy \& Practical Therapeutics. Hospital Pharmacy, Erasmus University Medical Centre. Rotterdam (The Netherlands).

Steven SIMOENS. MSc. Professor Pharmaco-economics. Research Centre for Pharmaceutical Care \& Pharmacoeconomics, K U Leuven. Leuven (Belgium). but also needs to account for the loss of income to pharmacists from prohibiting discounting practices.

Keywords: Drugs, Generic. Drug Substitution. Fees, Pharmaceutical. Pharmacists. Europe.

\section{¿CÓMO PUEDEN CONTRIBUIR LOS SISTEMAS DE REMUNERACIÓN FARMACÉUTICA A LA DISPENSACIÓN DE MEDICAMENTOS GENÉRICOS?}

\section{RESUMEN}

Los medicamentos genéricos pueden producir mayores ahorros a los presupuestos sanitarios cuando se apoyan con incentivos tanto a la oferta como a la demanda. La remuneración de los farmacéuticos es un factor que influye en la dispensación de medicamentos genéricos. Objetivos: El objetivo de este artículo es proporcionar una revisión de diferentes sistemas remunerativos de medicamentos genéricos en Europa, con idea de explorar con la remuneración de los farmacéuticos puede contribuir a la dispensación de genéricos.

Métodos: Se obtuvieron datos de una revisión de la literatura, de una tesis de Master en Atención Farmacéutica en la Universidad Católica de Lovaina, y de un correo enviado a todos los miembros del Grupo Farmacéutico de la Unión Europea solicitando información sobre los sistemas locales de remuneración de farmacéuticos comunitarios y la posible existencia de informes sobre las prácticas de descuentos.

Resultados: La remuneración de los farmacéuticos en la mayoría de los países europeos consiste en la combinación de una tasa fija por artículo y un cierto porcentaje del precio de compra o del precio de venta del medicamento. Este componente porcentual puede ser fijo, regresivo o con topes para los medicamentos de muy alto coste, y actúa como un desincentivo para dispensar medicamentos genéricos. Los descuentos para medicamentos genéricos son practica común en varios países Europeos, pero la información sobre esta práctica tiende s ser confidencial. Sin embargo, los datos de Bélgica, Francia, Holanda y Reino Unido indican que los porcentajes de descuento varían del $10 \%$ al $70 \%$ del precio del mayorista.

Conclusión: Los farmacéuticos pueden jugar un papel importante en el desarrollo del mercado de genéricos. No se debería penalizar financieramente a los farmacéuticos por dispensar genéricos. Por tanto, su remuneración debería moverse hacia una tasa-por-acto en lugar de un rembolso precio- 
dependiente, que es lo que ocurre en la mayoría de los países Europeos. Este sistema de remuneración en tasa-por-acto produce estímulos para la dispensación de genéricos, ya que los farmacéuticos no son penalizados por dispensarlos, pero también necesita tener en cuenta las pérdidas de ingresos al prohibir las prácticas de descuentos.

Palabras clave: Medicamentos Genéricos. Sustitución de Medicamentos. Honorarios Farmacéuticos. Farmacéuticos. Europa.

\section{INTRODUCTION}

Health care budgets have been continuously increasing in European countries and governments are looking for ways to curb these rising costs. ${ }^{1}$ Generic medicines have caught the attention of European governments and third-party payers as an opportunity to create savings on the budget as prices of generic medicines tend to be $10-80 \%$ lower than those of their originator equivalents. ${ }^{2}$ Generic medicines are substitutes for original medicines with the same active ingredient and the same quality, safety and efficacy. ${ }^{3}$ In order to maximize the potential savings of generic medicines, a coherent set of policies on both the supply-side and the demand-side is needed to develop a generic medicines market. Supply-side policies include incentives for physicians (e.g. budgetary incentives, prescription monitoring.), pharmacists (e.g. generic substitution) and patients (e.g. patient co-payment). ${ }^{2}$

Retail pharmacists are an important target for policy-makers in their attempt to develop a generic medicines market. Some countries have already implemented policies for pharmacists to encourage the use of generic medicines. Generic substitution for instance, a policy where pharmacists can dispense a generic version of the medicine when the physician has prescribed an originator medicine, has already been installed in 14 European countries. ${ }^{4}$ However, this policy can only work if the dispensing of generic medicines is financially neutral or attractive compared with the dispensing of their originator equivalents. It is therefore important that pharmacists' remuneration is adjusted so that they are not financially penalized for dispensing generic medicines, as some countries have already tried by means of margin equalisation, regressive margins or fee-forperformance systems. ${ }^{2}$ These governmental policies are sometimes politically motivated, so the policies change together with the continuously changing political landscape.

A part of pharmacists' remuneration could also be formed by discounts on generic medicines, a tactic used by manufacturers to increase their market share or by governments to partially remunerate pharmacists. As this practice is surrounded by confidentiality, only little is known about the existence and the extent of discounts.

The aim of this article is to provide an overview of the different pharmacist remuneration systems for generic medicines in Europe, with a view to exploring how pharmacist remuneration systems can contribute to generic medicine dispensing. The article will focus specifically on discounting practices as a component of pharmacist remuneration systems.

\section{METHODS}

Studies were identified by searching Pubmed, EMBASE, Cochrane Database of Systematic Reviews, NHS EED and Econlit. Bibliographies of included studies were checked for other relevant studies. In addition, various websites of European and national competent authories were searched for up-to-date data and reports.

A mailing was sent to all members of the Pharmaceutical Group of the European Union (PGEU), the European association representing community pharmacists, with a request for information about the local remuneration systems of community pharmacies and the possible existence of reports on discounting practices.

Data on discounting practices in Belgium were derived from a Master thesis in Pharmaceutical Care supervised by SS and PD. ${ }^{5}$ A group of fifthyear pharmacy students conducted a survey where 11 generic manufacturers, four wholesalers and six pharmacies were questioned about the discounts from manufacturers. The questioned active substances were selected out of the top 30 of active substances which constituted the largest cost for the Belgian third-party payer in 2009. Eleven active substances with oral generic alternatives where selected in this way. "The pharmacists were questioned about the amplitude of the discounts per active substance, the size of the purchase to obtain discounts and other rules or agreements in connection with discounts. ${ }^{5}$

\section{RESULTS}

Our results focus specifically on pharmacist remuneration for generic medicines. The mailing sent to the PGEU with a request for information about the local remuneration systems of community pharmacists and the possible existence of reports on discounting practices resulted in responses from Austria, Belgium, Finland, Germany, the Netherlands and Italy. Results for other countries were obtained by the literature review.

Pharmacists' remuneration for generic medicines differs among European countries and is usually based on a fee-for-service basis in addition to the reimbursement of the acquisition costs for the dispensed medicines. The calculation of the remuneration component for dispensing reimbursed generic medicines is usually based on: (a) a fixed fee per item; (b) a certain percentage of the acquisition cost or the delivery price of the medicines; or (c) a combination of the two. The percentage component can be fixed, regressive or capped for very high-cost medicines. Table 1 provides an overview of the pharmacies' remuneration systems for reimbursed generic medicines in 14 European countries for which data were available. 


\begin{tabular}{|c|c|c|c|c|c|c|c|c|c|c|c|c|c|c|c|c|c|c|c|c|}
\hline & & 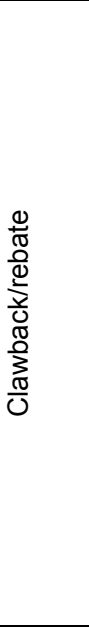 & 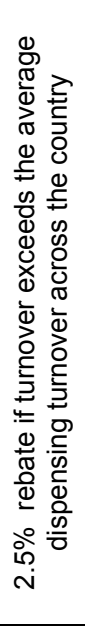 & ' & & ' & 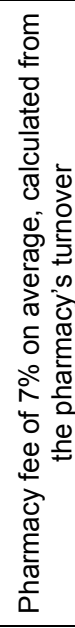 & & 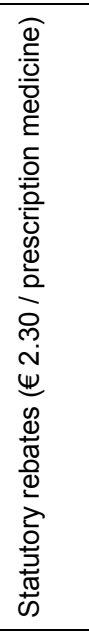 & 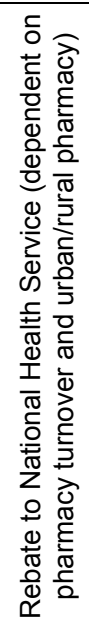 & 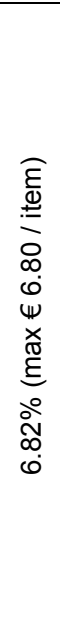 & & & & ' & 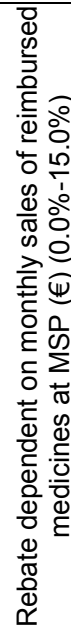 & & & 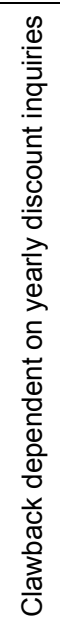 & 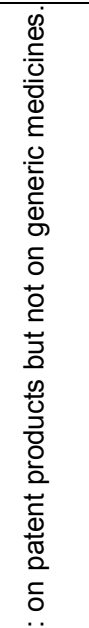 \\
\hline & & 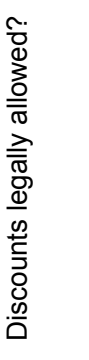 & $\stackrel{\infty}{\nu}$ & $\stackrel{\infty}{\nu}$ & & $\stackrel{\infty}{\nu}$ & ㅇ & 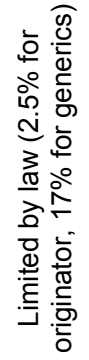 & 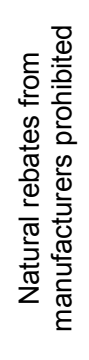 & $\stackrel{\infty}{\infty}$ & $\stackrel{\infty}{\infty}$ & zo & & $\stackrel{\infty}{\nu}$ & $\stackrel{\infty}{\nu}$ & 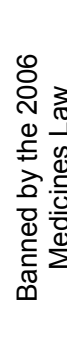 & & $\begin{array}{l}0_{0}^{\infty} \\
\stackrel{\infty}{\infty}\end{array}$ & $\stackrel{\infty}{\nu}$ & 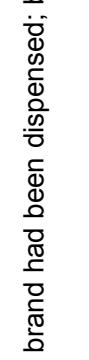 \\
\hline $\begin{array}{l}\stackrel{0}{0} \\
\stackrel{0}{\frac{0}{0}}\end{array}$ & & 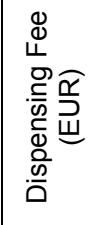 & ' & $\begin{array}{l}\stackrel{E}{\stackrel{E}{\rightleftharpoons}} \\
\stackrel{\infty}{\infty} \\
\infty \\
\sim\end{array}$ & & 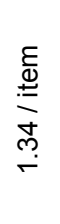 & 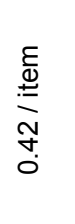 & 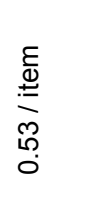 & 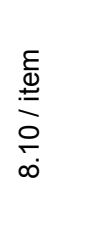 & & 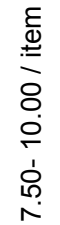 & $\begin{array}{l}\stackrel{E}{\stackrel{E}{\Xi}} \\
\stackrel{i}{N}\end{array}$ & & & ' & ' & & & $\stackrel{\infty}{\nu}$ & 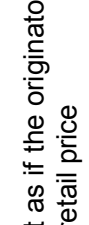 \\
\hline 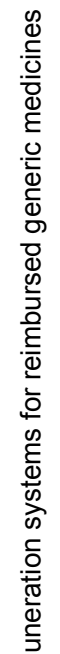 & 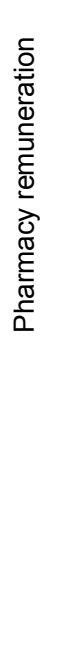 & 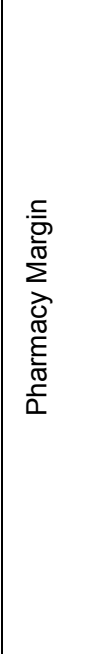 & 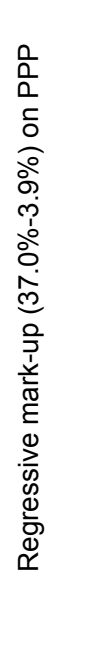 & 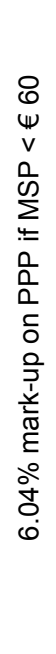 & 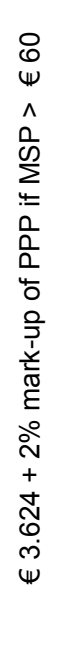 & 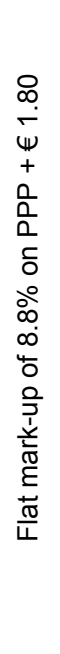 & 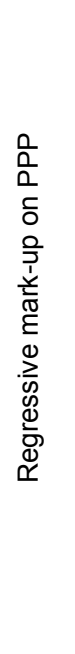 & 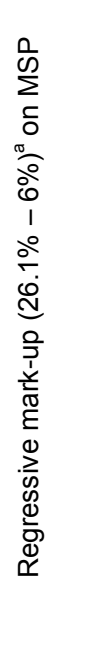 & 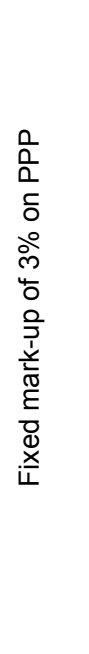 & 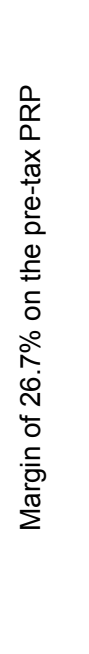 & 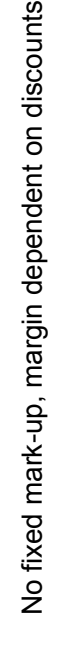 & 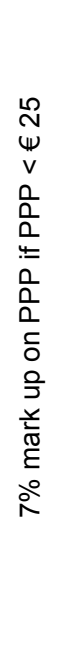 & 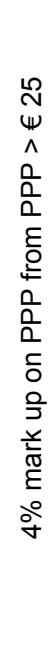 & 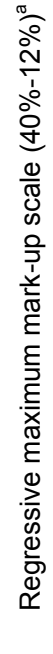 & 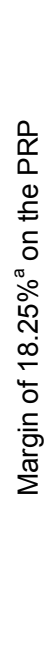 & 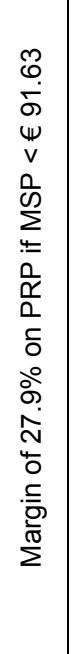 & 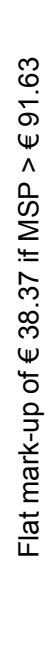 & 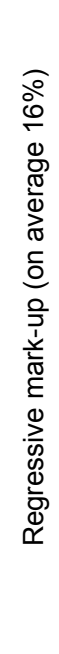 & 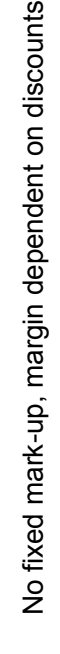 & 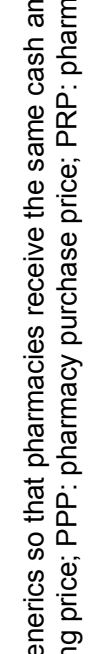 \\
\hline 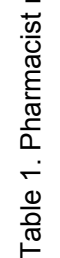 & & & 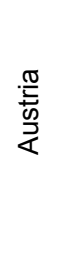 & $\begin{array}{l}\frac{E}{D} \\
\frac{D}{0} \\
\frac{D}{0}\end{array}$ & & 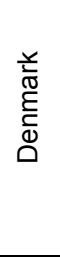 & 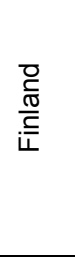 & 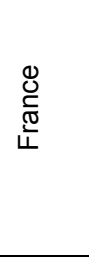 & 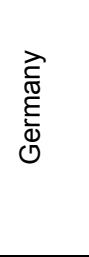 & $\stackrel{\text { त्ञ }}{ \pm}$ & 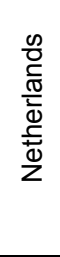 & $\begin{array}{l}\text { त) } \\
\sum_{0}^{0} \\
z\end{array}$ & & $\begin{array}{l}\text { 뜌 } \\
0 \\
0\end{array}$ & 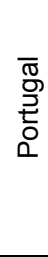 & $\begin{array}{l}\text { 高 } \\
\text { ळ }\end{array}$ & & $\begin{array}{l}c \\
\frac{c}{0} \\
\text { d } \\
\sum_{0}^{\infty}\end{array}$ & 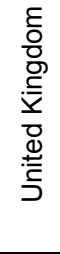 & 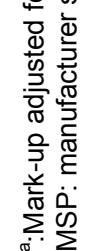 \\
\hline
\end{tabular}


Discounting of generic medicines is common practice in several European countries and discounts can make up some part of pharmacists' remuneration. Information about the amplitude of discounts to pharmacists is hard to find as this practice is surrounded by confidentiality. Data on discounts were found for four countries (Belgium, France, the Netherlands and the United Kingdom). In the Netherlands and the United Kingdom, reports discussing discounts are publicly available as governments rely partly on discounting practices to remunerate pharmacists. ${ }^{7}$

In the Netherlands, the Dutch Health Care Authority (NZa) conducts yearly audits of the purchasing benefits (discounts) of pharmacies for the calculation of the tariffs. The average purchasing benefits for reimbursed medicines declined from $19.9 \%$ in 2007 to $12.5 \%$ in $2009 .^{8}$ As part of an operation to achieve savings, the State Secretary of Health decided to reduce the dispensing fees in 1991. In connection with this measure, the government has allowed the pharmacies to keep the purchasing advantages (i.e. discounts) as they compensate the shortfall in dispensing fees. ${ }^{9}$ In order to balance their budget however, the government has installed a claw-back, which is currently set on $6.82 \%$, with a maximum of 6.80EUR per dispensed medicine. ${ }^{9}$ The claw-back is a mechanism whereby the government tries to recover some of the benefits obtained by the pharmacists.

In the United Kingdom, the Department of Health conducts yearly discount inquiries to estimate the average levels of discount. ${ }^{7,10}$. To recover some of these discounts, the United Kingdom uses the yearly discount inquiries to calculate the claw-back, which ranges from $5.63 \%$ to $11.5 \%$ of a pharmacy's total monthly reimbursement. A study of Kanavos however disclosed that average discount levels were far beyond this claw-back range. For $64.5 \%$ of the reviewed medicines, the discount levels exceeded $60 \%$ while average discount levels were between $50 \%$ and $60 \%$ for $22.6 \%$ of the reviewed medicines. ${ }^{11}$ The average discount levels thus exceeded the claw-back rates.

In France, the government has installed maximum allowable discount ceilings for pharmacists, which are $2.5 \%$ for branded products and $17 \%$ for generic products. ${ }^{12}$ By regulating them, the government expects pharmacists to dispense generic medicines as they will benefit from higher discount percentages. A study in 2007 however suggested that discounts for products with generic alternatives exceeded this limit. The discounts generally varied from $20 \%$ to $70 \%$ of the wholesale selling price, on top of the at that moment allowed discount of $10.74 \% .{ }^{13}$ The amplitude of the discounts varied also significantly between the investigated pharmacies.

Discounting percentages in Belgium were derived from a Master thesis. ${ }^{5}$ Eight manufacturers and two wholesalers participated in the survey but did not disclose any details about the extent of the discounts. All pharmacies confirmed the existence of discounts but only four were willing to give data on the amplitude of these discounts. Only a general discounting percentage per active substance and per manufacturer was provided and this was on average around $27 \%$ but variations occurred, both between pharmacies and between manufacturers. Discounts of manufacturers with a large market share in Belgium were on average $28 \%$ whilst those of small manufacturers were on average $26 \%$. The discounts also varied between pharmacies as one manufacturer gave an average discount of $26 \%$ to one pharmacy while another pharmacy received an average discount of $29 \%$ for the same products. ${ }^{5}$

\section{DISCUSSION}

Generic medicines are essential contributors for sustaining health care budgets and therefore, pharmacists play a crucial role by dispensing generic medicines. Pharmacists' remuneration differs between European countries and this influences dispensing patterns of generic medicines. In some countries for example, pharmacists are financially penalized for dispensing cheaper, more cost-effective generic medicines (e.g. Italy, Spain). ${ }^{4,14}$ As this acts as a disincentive for the development of a generic medicines market, pharmacists' remuneration for dispensing generic medicines should at least be financially equal to that of originator medicines. Governments have to adapt their remuneration systems for pharmacists in order to stimulate the dispensing of generic medicines.

In countries where the remuneration of pharmacists is set as a percentage of the medicine's price, margins for generic medicines are usually lower than those of their originator equivalent because of the lower prices of generic medicines. Some countries use the principle of margin equalization, where the pharmacists have a guaranteed absolute margin for the generic medicines equal to that of the originator medicine. ${ }^{14}$ Pharmacists are not financially penalized for dispensing generic medicines with this system but prices of generic medicines increase relative to originator medicines because of this absolute margin. Competitive prices of generic medicines are thus not achieved and savings for governments through the use of generic medicines are not optimally exploited. Other countries have tried to address the problem by implementing regressive scales, but the regressive effect of such scales tends not to be sufficient to remove the financial incentive for dispensing originator medicines. ${ }^{2}$

Another way of avoiding financial penalization for pharmacists would be to replace the current pricedependent reimbursement (where pharmacists are remunerated dependent on the medicine's price), used in many European countries, by a fee-perperformance payment (where pharmacists are remunerated dependent on the pharmacists' actions). ${ }^{15}$ Pharmacists need to be rewarded for their knowledge and their actions with regards to pharmaceutical care (e.g. dispensing fee, counseling patients, guidance when dispensing medicine for first time, etc.), much like physicians. ${ }^{16,17}$ Some countries have already moved towards such a system. Belgium for example 
remunerates pharmacists by a fixed honorarium per dispensed medicine plus a small economic margin of $6.04 \%$ plus extra fees for specific forms of pharmaceutical care. Also the Netherlands will be introducing a fee-for-performance remuneration for pharmacists at the beginning of 2012. When pharmacists are remunerated following this fee-forperformance principle, prices of the medicines will not determine the remuneration and pharmacists would have no disincentive to dispense generic medicines.

Discounts are officially part of pharmacists' remuneration in some countries (e.g. the Netherlands, United Kingdom), but also occur in other countries, whether or not this is legally allowed. France, for example, has regulated discounting to stimulate pharmacists for dispensing generic medicines. Pharmacists are thus rewarded for their negotiating skills rather than for services rendered. This system might be financially beneficial for wholesalers and pharmacies but is not sustainable in the long term. ${ }^{18}$ Health care budgets and patients miss out on the possible savings of the generic medicines market when manufacturers compete on discounts. This is also what a study of the Norwegian Audit Office concluded: prices and distribution margins of generic medicines in Norway were considered to be too high as a result of discounting practices. ${ }^{19}$ Health care payers are thus overpaying for medicines and have taken policies to recoup some of the discounts. For instance, the Netherlands and United Kingdom have installed a claw-back mechanism to recover some of the discounts given to pharmacies and France has regulated the maximum size of the discounts. ${ }^{8,10,13}$ However, this type of government intervention is unlikely to be as efficient as a system where manufacturers compete on the basis of prices. As discounting practices are surrounded by confidentiality and not transparent to all market actors, the size of actual discounts may go beyond the size of the claw-back. ${ }^{11,13}$

Therefore, we recommend that discounts are prohibited. For instance, the Polish government has introduced legislation outlawing discounting to the medicine distribution chain and promoting price competition from January 2012 onwards. However, such legislation also needs to address the issue of pharmacist remuneration as pharmacists are likely to lose an important source of income when discounts are outlawed. ${ }^{18,20}$ In the Netherlands, the government has installed the preference policy as an answer to, amongst other things, discounts to pharmacists. By this preference policy, health insurers instead of pharmacists will negotiate with manufacturers of medicines and reimburse only the medicine with the lowest price. The policy has caused a decrease of prices of medicines by 76 $96 \%$ and this has endangered the sustainability of pharmacies and the delivery of drugs. ${ }^{21}$

The data on the size of the discounts suffer from the fact that the estimation is made on a small sample of pharmacies. In the United Kingdom, the discount inquiries do not include chain pharmacies, which constitute $50 \%$ of all pharmacies in the United Kingdom. As chain pharmacies have more purchasing power, the average discount levels could be underestimated. Data used for France and Belgium were derived from four pharmacies only in each country, so the discount levels found in these studies may be indicative but not representative. ${ }^{5,13}$

This article provides only a snapshot of the remuneration systems for pharmacists in European countries. As these policies evolve continuously, the features of the remuneration systems shown in this article could already be outdated.

\section{CONCLUSIONS}

Pharmacists can play an important role for the development of a generic medicines market. In order to contribute to generic medicine dispensing, pharmacists' remuneration needs to move towards a fee-for-performance remuneration instead of a price-dependent reimbursement which is currently used in many European countries. Such a fee-forperformance remuneration system provides a stimulus for generic medicines dispensing but also needs to account for the loss of income to pharmacists from prohibiting discounting practices.

\section{CONFLICT OF INTEREST}

Steven Simoens holds the EGA Chair "European policy towards generic medicines". The authors have no conflicts of interest that are directly relevant to the content of this manuscript.

\section{References}

1. Godman B, Shrank W, Wettermark B, Andersen M, Bishop I, Burkhardt T, Garuolienè K, Kalaba M, Laius O, Joppi R, Sermet C, Schwabe U, Teixeira I, F. Tulunay C, Wendykowska K, Zara C, Gustafsson LL. Use of generics - A critical cost containment measure for all healthcare professionals in Europe? Pharmaceuticals. 2010;3:2470-2494.

2. Simoens S, De Coster S. Sustaining generic medicines markets in Europe. Leuven, Belgium: K U Leuven; 2006. Available at: www.egagenerics.com [Last accessed: 15 November 2011]

3. Directive 2004/27/EC of the European Parliament and of the Council of 31st March 2004 amending Directive 2001/83/EC on the Community code relating to medicinal products for human use. Official Journal of the European Union L 136/34-57, European Commission, (2004).

4. European Generic Medicines Association. 2011 Market Review. Brussels, Belgium: European Generic Medicines Association; 2011.

5. Carpentier $P$, Louwies L, Otten $P$, Van Cakenbergh A, Van Laethem L, Verbruggen $K$. Research on pricing strategies and discounts on generic drugs and the impact of the new remuneration system for pharmacists in Belgium. Leuven, Belgium: K.U.Leuven; 2011.

6. RIZIV/INAMI. Overall analysis report on the content of Farmanet - unique track. Brussels, Belgium: RIZIV/INAMI; 2009. 
7. Macarthur D. European pharmaceutical distribution: Key players, challenges and future strategies. London, United Kingdom: SCRIP Reports; 2007. Report No.: BS1353. Available at: http://www.scripintelligence.com/multimedia/archive/00000/BS1353_124a.pdf [Last accessed: 18 November 2011]

8. Nederlandse Zorgauthoriteit (NZa). Purchasing advantages and practice costs for pharmacies 2009,2010 and 2011. Utrecht, the Netherlands: Nederlandse Zorgauthoriteit; 2010. Available at: http://www.farmaactueel.nl/beleidsstukken/rapport-inkoopvoordelen-apotheekhoudenden-2009.pdf [Last accessed 18 November 2011]

9. Stichting Farmaceutische Kengetallen. Facts and figures 2011: 2010 in numbers. Stichting Farmaceutische Kengetallen; 2011. Available at: http://www.sfk.nl/publicaties/data_en_feiten.html [Last accessed: 18 November 2011]

10. Office of Fair Trading. Medicines distribution: an OFT market study. London, United Kingdom: Office of Fair Trading; 2007. Available at: http://www.sfk.nl/publicaties/data_en_feiten.html [Last accessed: 21 November 2011].

11. Kanavos P. Do generics offer significant savings to the UK National Health Service? Curr Med Res Opin 2007;23(1):105-116.

12. Pharmaceutical Pricing and Reimbursement Information. France: pharma profile. Vienna, Austria: PPRI; 2008. Available at : http://whocc.goeg.at/ [Last accessed: 18 November 2011]

13. Kanavos $P$, Taylor D. Pharmacy discounts on generic medicines in France: is there room for further efficiency savings? Curr Med Res Opin. 2007;23(10):2467-2476.

14. European Generic Medicines Association. How to increase patient access to generic medicines in European healthcare systems. Brussels, Belgium: European Generic Medicines Association; 2009. Available at: www.egagenerics.com [Last accessed: 16 November 2011]

15. Schwermann T, Greiner W, v.d.Schulenberg G. Using disease management and market reforms to address the adverse economic effects of drug budgets and price and reimbursement regulations in Germany. Value Health. 2003;6(1):20-30.

16. Silversides A. Pharmacies receiving massive rebates from generic drug-makers. CMAJ. 2006;175(4):342-343.

17. Bernsten C, Andersson K, Gariepy Y, Simoens S. A comparative analysis of remuneration models for pharmaceutical professional services. Health Policy. 2010;95:1-9.

18. Simoens S. Generic medicine pricing in Europe: current issues and future perspective. J Med Econ. 2008;11:171-5.

19. IHS Global Insight. National audit office finds further room for generic-associated savings in Norway. Lexington, Massachuchets: IHS Global Insight; 2011. Available at: http://www.ihsglobalinsight.com/SDA/SDADetail16273.htm [Last accessed: 17 November 2011]

20. Simoens S. Developing competitive and sustainable Polish generic medicines market. Croat Med J. 2009;50:440-448.

21. Boonen L, van der Geest S, Schut F, Varkevisser M. Pharmaceutical policy in the Netherlands: from price regulation towards managed competition. Adv Health Econ Health Serv Res. 2010;22:53-76. 